\title{
Analysis of the Effect of Water Flux to a Gas Zone after Through Tubing Perforations on Gas Production by Numerical Simulations
}

\author{
Şükrü Merey* \\ Batman University, Department of Petroleum and Natural Gas Engineering, Batman, Turkey \\ *sukru.merey@batman.edu.tr
}

Received: 16 November 2018

Accepted: 11 February 2019

DOI: $10.18466 /$ cbayarfbe. 483578

\begin{abstract}
After perforating a gas zone with through tubing perforation method, other possible gas zones are also perforated from bottom to top accordingly. However, if one of these zones is highly saturated with water, water might flow through the perforations where gas production is possible. In this study, the water flux from upper perforation to lower perforations where gas is available was simulated by using TOUGH + RealGasBrine simulator. The effects of permeability, pressure differences between zones, and salinity on water flux through gas zone were investigated in this study. Permeability affects the behavior of water flux and its amount to gas zone significantly. Similarly, these effects were seen for the cases with pressure differences between zones and salinity in water zone even though these effects are less than those observed in permeability cases. It was observed that the duration of exposure of gas zone to water flux should be kept minimum by applying well completion operations quickly to isolate water zone and stop water flux from this zone to gas zone. After isolating water zone with well completion operations, gas production simulations from gas zone were conducted at a constant production pressure of $5 \mathrm{MPa}$. It was observed that gas production from gas zone was retarded and water production from gas zone was higher compared to the original cases without any water invasion. Even in a long term of gas production, it is possible to observe the remarks of previous water flux from upper zone after analyzing water saturation distribution.
\end{abstract}

Keywords: Gas reservoirs, perforation, simulation, through tubing, water invasion, well completion.

\section{Introduction}

During gas production from gas wells, liquid water and/or condensate are produced as well. When reservoir pressure decreases with production, gas flow velocity declines due to the reduction in the carrying capacity of gas. Then, liquid water accumulates inside the well and gas production rate drops [1]. This is called liquid loading and the risks of liquid loading for each gas well should be investigated. Turner's entrained droplet model is the most common method used to predict possible liquid loadings in gas wells [2]. Differently, in fractured gas reservoirs, it is possible to observe water coning problem, which reduces gas production rate significantly [3]. Overall, water is a nuisance for gas producing wells [4]. Although water saturation is low in a gas well, possible invasions of water through gas zones can surpass gas production enormously due to poor well completion operations. Furthermore, water flow from aquifers through perforations in gas wells because of casing leaks and poor cementing can decrease gas production. For these reasons, water is considered as nuisance in gas wells [5].

Well completion of gas reservoirs is crucial because it might affect the efficiency of gas production significantly. Well log data is also important to decide on the intervals of perforations of gas zones. Water saturation and gas saturation are commonly used in order to decide on perforation intervals. Generally, if gas zones include high water saturations, these zones are not perforated. Hence, the correct analysis of well logs for detecting possible gas zones is essential. For instance, in the East-Delta Area of Egypt, gas is produced from the Messinian Abu Madi sandstones, fine to very fine grained sandstone with abundant laminations of shales. By conventional logging analysis, one gas layer with approximately $70 \%$ water saturation was found but this discouraged the perforation of this interval [6]. Islam et al. [7] evaluated the well log data of Bakhrabad-10 well in Nasingdi Gas Field in Bangladesh. From 12 permeable zones, only 5 zones (2915-2617 m; 2993-2996; 3131$3134 \mathrm{~m} ; 3145-3149 \mathrm{~m} ; 3166-3169 \mathrm{~m}$ ) were defined as gas-bearing zones (with 23-31\% porosity, 28-90 mD permeability and more than $65 \%$ gas saturation). The rests of zones (1850-1872 m; 1955-1950 m; 1972-1990 m; 2005-2018 m; 2145-2155 m; 2182-2198 m; 2225$2242 \mathrm{~m}$ ) were characterized by gamma ray (GR), selfpotential (SP), resistivity logs (MSFL and ILD), density $\log$ (RHOB) and neutron log (NPHI). Low GR, high SP, low RHOB, very low NPHI responses are some of the indicators of gas-bearing reservoirs. Higher true 
resistivity responses with respect to lower water resistivity responses and vice versa indicate that hydrocarbon type fluid is gas bearing in Bakhrabad-10 well [7].

There are different completion techniques to reduce water problems in gas wells. For example, downhole gas/water separation wells were designed to avoid liquid loading in gas wells [8]. However, there is not any study investigating the effect of water invasion to gas reservoirs after through tubing perforations by numerical simulations. After perforating a gas zone, the possible gas zones above this gas zone are also perforated depending on company's policy. However, these zones might include gas with high water saturations due to the wrong evaluation of well log data. It is possible to obtain wrong predictions of water and gas zones due to the complexity of multi-lateral gas reservoirs and the usage of wrong well $\log$ evaluation techniques (i.e. shale effects, gas effects, washouts etc.) [9]. After perforations, water might flow through gas producing perforations below water zone. It takes time to isolate these water-producing perforations. Until this time, water keeps flowing through gas producing perforations due to gravity difference and reservoir pressure differences. This problem is seen in gas wells but the effect of water invasion to gas producing zones after through tubing perforations has not been evaluated by modelling studies so far. In this study, it is aimed to investigate this effect on the gas production profile of gas producing zones by using TOUGH + RealGasBrine simulator because it is user-friendly and appropriate for scientific investigations compared to other commercial software such as GEM and ECLIPSE.

After drilling of a gas well, decision should be made whether this well is completed or not. Well logging data and drill stem test (DST) data are important to decide on this. In this study, the well completion of cased wells is considered. When it is reached to the target depth by drilling, production casing is lowered and cemented if it is aimed to complete the well. Then, well completion is necessary to start gas production from target gas production zones.

Well completion design is essential in five phases [10]:

- Design criteria should be established.

- Production zone(s) should be selected.

- The mechanical completion of well (i.e. perforations) should be organized carefully.

- After starting production, the test should be completed.

- The monitoring of well completion performance of well is essential during production.

For cased wells, perforations are essential. After the evaluation of well log data, the perforation intervals are selected. Wireline perforating (or through-casing perforation), tubing conveyed perforating (TCP), through tubing perforating (TTP) are commonly used methods in Figure 1. Wireline perforating cannot be used for gas wells and oil wells with high pressures because in this method, tubings are removed from well as seen in Figure 1-a. The size of wireline perforating equipment is generally larger than tubing sizes. When perforations of the desired intervals are completed via wireline perforating method, the equipment is pulled back to surface and tubings with RTTS (retrievable thru-tubing packer) packer is lowered to test production zone [11]. The main usage of packers is to isolate annulus of the wellbore and provide connection with only perforations [10]. Differently, tubing conveyed perforating (TCP) method is chosen to initiate gas production immediately just after perforation as shown in Figure 1-c. After drilling cementing plugs of production casing, casing is tested. If casing testing is successful, the tubing string of TCP is lowered to well. TCP string includes the following equipment from bottom to top:

- TCP guns and its cover

- Detonator (Firing pin)

- Sub inside which there is glass

- Packer (mostly perma-lach retrieveable production packer)

- Tubings
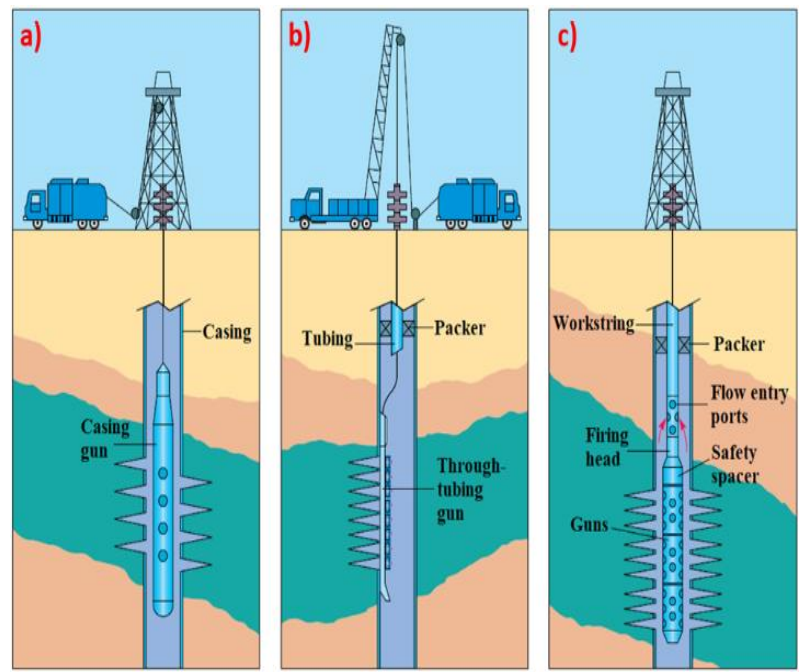

Figure 1. a) Through-casing perforation b) Throughtubing perforation (TTP) c) Tubing-conveyed perforation (TCP) [11].

TCP guns are lowered to the production interval and then packer is set to isolate annulus from the production zone in Figure 1-c. Due to the sub inside which there is glass, completion fluid cannot enter inside tubing. This is an advantage because after perforation, gas or oil in high pressure zones flow directly to surface via tubing. Perforation is completed when firing bar is dropped from the surface to the tubing inside. With gravity, firing bar breaks the glass of the sub and hits the detonator. This activates guns and perforations are opened. Then, gas or 
oil flow until Christmas tree (surface production wellhead equipment used in high pressurized wells). Then, flow rate and surface pressures can be measured to test production zone [10]. TCP method is used for perforating intervals at underbalance conditions with large diameter guns. TCP method reduces the rig time especially in long perforation intervals. However, TTP method is advantageous during perforating small intervals because it decreases multiple trips because of wireline perforating [10].

Differently, through tubing perforating (TTP) method is chosen to open perforations in high pressurized zone both before production and during production as seen in Figure 1-b. Basically, as cementing plugs are drilled and casing test is completed successfully, tubing string with production packer is lowered near the top of shallowest perforation zone. Then, packer is set to isolate annulus from the inside of tubing and perforation intervals. The charges inside a carrier are attached to hollow steel carrier guns. There is not any direct contact of charges with completion fluids. Guns are connected via cables to transfer the signal coming from wireline to guns for explosions. Depending on tubing sizes, depth, strength of perforation interval, etc., there are many alternatives of charges with different shot density and phasing [12].

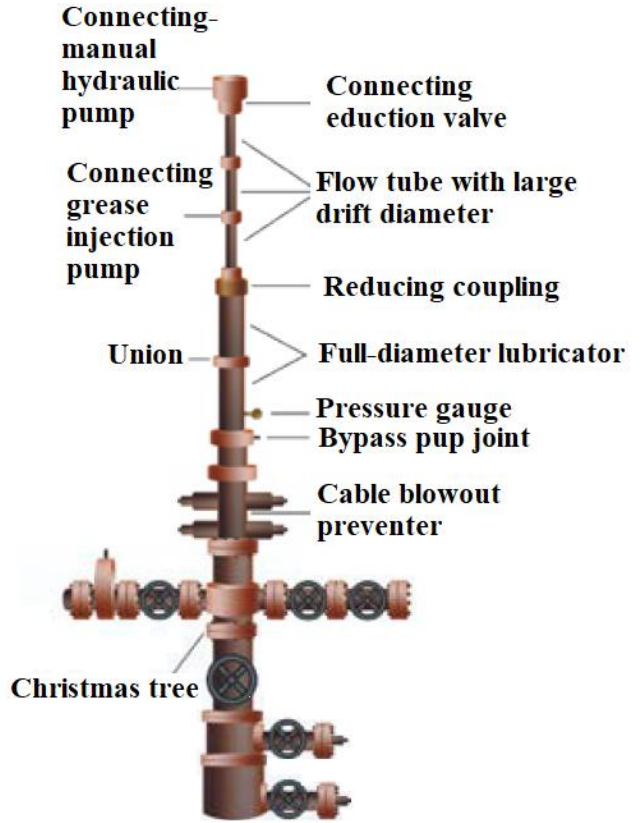

Figure 2. Well head and lubricator for TTP [13].

After preparing guns, they are lowered until the target zones inside tubing. Above Christmas tree, special well head equipment of TTP equipment (wireline lubricator) is inserted in Figure 2. This wireline lubricator provides sealing and it avoids gas seepages after perforation in Figure 2. Moreover, it makes possible lowering or pulling wireline without gas leaks in surface. It is possible to perforate different target zones at different depths of well quickly by this method. Moreover, new perforations can be opened with this system in the wells with an existing production tubing. With TTP equipment and guns passing inside the tubing, it is possible to perforate the target intervals without removing tubing string. TTP has different types of gun systems even for high pressure and high temperature conditions [13]. The main advantage of TTP method is that it can be conducted any time after completion without removing production string hanged on well head above which Christmas tree is connected. Moreover, in order to use TTP method in highly deviated well where electric line is limited, a novel technology was developed by Ifediora et al. [14].

In the Adriatic Sea of Italy, there are several gas offshore wells producing gas since 1960s. In these wells, gas production occurs from multilayer metric and submetric thin sand reservoirs (mainly turbiditic sequences of sands and shales). With the decline of gas production, several new perforations were opened via through tubing perforation technique (TTP) using $1^{11 / 16}$ " guns and good production results were obtained from new perforations. In this way, it was possible to increase gas production without any rig and opening new infill wells. Careful designs are essential during the opening of new perforations in producing wells. All risks (i.e. water invasion to gas-producing perforations) should be lowered before opening new perforations via TTP method. TTP method is applied in underbalance conditions and this decreases wellbore damage. In oil fields, good results were also obtained in order to increase oil production with this perforation method [15].

\section{Materials and Methods}

In this study, TOUGH + RealGasBrine simulator was chosen to investigate the effect of water invasion to gas zones after through tubing perforations (TTP) by numerical simulations. TOUGH + RealGasBrine v1.0 is a set of Fortran 95/2003 codes predicting the behavior of gas reservoirs, which was developed at the Lawrence Berkeley National Laboratory, USA. These gas reservoirs might be:

- Conventional gas reservoirs in which Darcy flow equations are valid during numerical simulations for gas production.

- Unconventional gas reservoirs (i.e. shale gas, tight gas) in which Darcy flow equations are invalid during numerical simulations for gas production so nonDarcy equations are chosen for these reservoirs.

- Fractured gas reservoirs.

- Reservoirs for natural gas storage or $\mathrm{CO}_{2}$ sequestration.

For such complex reservoirs, it is essential to predict the flow equations for multicomponent, multiphase and heat flow equations. Hence, non-isothermal two or three phase flow of aqueous phase and a real gas mixture are predicted with TOUGH + RealGasBrine. Permeability values for unconventional gas reservoirs are in the range of $\mathrm{nD}$ (nano Darcy) $\left(10^{-21} \mathrm{~m}^{2}\right)$. Darcy equation does deviate in these conditions and other non-Darcy 
equations (i.e. full micro-flow treatment with Knudsen diffusion, gas slippage effect with Klinkenberg, Dusty gas model) are essential to predict the transport of phases [16]. Another important option of TOUGH + RealGasBrine is that up to 12 individual real gases $\left(\mathrm{CH}_{4}\right.$, $\mathrm{C}_{2} \mathrm{H}_{6}, \mathrm{C}_{3} \mathrm{H}_{8}, \mathrm{n}-\mathrm{C}_{4} \mathrm{H}_{10}, \mathrm{i}-\mathrm{C}_{4} \mathrm{H}_{10}, \mathrm{H}_{2} \mathrm{O}, \mathrm{CO}_{2}, \mathrm{H}_{2} \mathrm{~S}, \mathrm{O}_{2}, \mathrm{~N}_{2}$, $\mathrm{C}_{2} \mathrm{H}_{5} \mathrm{OH}$, and $\mathrm{H}_{2}$, of which only $\mathrm{H}_{2} \mathrm{O}, \mathrm{CO}_{2}$ and $\mathrm{C}_{2} \mathrm{H}_{5} \mathrm{OH}$ are condensable) can be tracked and the precipitation of salt $(\mathrm{NaCl})$ in aqueous phase as solid (halite) can be predicted. Moreover, it is possible to observe the effect of the precipitation of salt as halite on porosity and permeability. Especially, for coalbed methane reservoirs and shale gas reservoirs, gas adsorption becomes important. For this reason, several adsorption isotherm options (i.e. mainly Langmuir isotherm) are available in the codes of TOUGH + RealGasBrine to predict the change in the amount of adsorbed gas during gas production or gas injection.

Table 1 lists the main equations used during the numerical simulations in this study with TOUGH + RealGasBrine (see nomenclature for definitions of all symbols used). Mass and heat balance considerations in every subdomain (grid-block) into which the simulation domain is subdivided by the integral finite difference method [16]. There are non-linear equations to be solved in TOUGH + RealGasBrine so discretization is done in order to make the equations linear. The Newton-Raphson iteration and Jacobian matrix were evaluated by numerical differentiation to determine primary variables at every stages of the simulations. A detailed description of the code, its underlying physics and capabilities of the numerical techniques and of the various options can be found in Moridis and Freeman [16].

Equation 2.1 is commonly used in TOUGH family codes to consider mass and heat balance. After assigning primary variables to each grids, it is possible to estimate water in place, gas in place and salt content by Equation 2.2. Different than previous TOUGH codes (i.e. TOUGH + Hydrate), the amount of gas adsorbed (if it is valid) can be estimated by Equation 2.2 in TOUGH + RealGasBrine. During gas production, gas injection, water production, or water injection, the primary variable values change and these changes are estimated by using the equations in Table 1. Equation 2.3 and Equation 2.4 are generally used for aqueous and gaseous phases respectively for Darcy flow but these equations cannot be used for tight and shale gas reservoirs.

As seen in Figure 3-a, when the flow channels are very large compared to the mean free path of the gas molecules, viscous flow occurs and Darcy's law is valid in this case. This flow behavior is common in conventional oil and gas reservoirs and flow equations are solved with Darcy's law [16]. However, this law is not valid if the accumulation of gas molecules on the surface of pores and this flow behavior is defined as slip flow (Figure 3-b). In shale gas reservoirs, especially matrix permeability and porosity are very small. When the flow channels are very small compared to the mean free path of the gas molecules, Knudsen flow behavior (Figure 3-c) is observed as in shale gas reservoirs. Moreover, Darcy's law is not valid in Knudsen flow [17]. TOUGH + RealGasBrine allows to users to choose Darcy law or non-Darcy flow. Knudsen flow, turbulent flow, Klinkenberg effects, and slippage effects are options that can be chosen by users [16]. Knudsen number equation is the ratio of the gas mean free path $(\lambda)$ and pore diameter (d). Knudsen number is smaller if pore diameter is larger. For viscous flow in Figure 3-a, it is less than 0.01 and Darcy law is valid in this case. It is between 0.01 and 0.1 for slip flow in Figure 3-b. The transition flow occurs if Knudsen flow is between 0.1 and 10 [18].

Table 1. Governing equations of fluid and heat flow in TOUGH+RealGasBrine [16].

\begin{tabular}{|c|c|c|}
\hline Description & Equation & $\begin{array}{l}\text { Equation } \\
\text { Number }\end{array}$ \\
\hline $\begin{array}{l}\text { Mass and } \\
\text { Energy } \\
\text { Conservation }\end{array}$ & $\begin{array}{l}\frac{d}{d t} \int_{V_{n}} M^{\kappa} d V= \\
\int_{\Gamma_{n}} F^{\kappa} \cdot n d A+\int_{V_{n}} q^{k} d V\end{array}$ & (2.1) \\
\hline $\begin{array}{c}\text { Mass } \\
\text { Accumulation }\end{array}$ & $\begin{array}{l}\mathrm{M}^{\mathrm{\kappa}} \\
=\sum_{\beta: \mathrm{A}, \mathrm{G}, \mathrm{H}} \varphi \mathrm{S}_{\beta} \rho_{\beta} \mathrm{X}_{\beta}^{\mathrm{\kappa}} \\
+\delta_{\psi}^{\mathrm{i}}(1-\varphi) \rho_{\mathrm{R}} \psi^{\mathrm{i}}, \mathrm{\kappa}: \mathrm{w}, \mathrm{g}^{\mathrm{i}}, \mathrm{s}\end{array}$ & (2.2) \\
\hline $\begin{array}{l}\text { Mass Flux } \\
\text { (aqueous } \\
\text { phase)-Darcy } \\
\text { Equation }\end{array}$ & $\begin{array}{l}\mathrm{F}_{\mathrm{A}}=-\mathrm{k} \frac{\mathrm{k}_{\mathrm{rA}} \rho_{\mathrm{A}}}{\mu_{\mathrm{A}}}\left(\nabla \mathrm{P}_{\mathrm{A}}-\rho_{\mathrm{A}} \mathrm{g}\right), \\
\kappa: \mathrm{w}, \mathrm{g}^{\mathrm{i}}, \mathrm{s}\end{array}$ & (2.3) \\
\hline $\begin{array}{l}\text { Mass Flux } \\
\text { (gas phase)- } \\
\text { Darcy } \\
\text { Equation }\end{array}$ & $\begin{array}{l}\mathrm{F}_{\mathrm{G}}^{\mathrm{\kappa}}=-\mathrm{k}\left(1+\frac{\mathrm{b}}{\mathrm{P}_{\mathrm{G}}}\right) \frac{\mathrm{k}_{\mathrm{rG}} \rho_{\mathrm{G}}}{\mu_{\mathrm{G}}} \mathrm{X}_{\mathrm{G}}^{\mathrm{\kappa}}\left(\nabla \mathrm{P}_{\mathrm{G}}-\right. \\
\left.\rho_{\mathrm{G}} \mathrm{g}\right)+\mathrm{J}_{\mathrm{G}}^{\mathrm{K}}, \kappa: \mathrm{w}, \mathrm{g}^{\mathrm{i}}\end{array}$ & (2.4) \\
\hline $\begin{array}{l}\text { Micro-Flows, } \\
\text { Knudsen } \\
\text { Diffusion }\end{array}$ & $\begin{array}{c}\frac{\mathrm{b}}{\mathrm{P}_{\mathrm{G}}}=\left(1+\alpha_{\mathrm{K}} \mathrm{K}_{\mathrm{n}}\right)\left(1+\frac{4 \mathrm{~K}_{\mathrm{n}}}{1+\mathrm{K}_{\mathrm{n}}}\right) \\
-1 \\
\alpha_{\mathrm{K}}=\frac{128}{15 \pi^{2}} \tan ^{-1}\left(4 \mathrm{~K}_{\mathrm{n}}^{0.4}\right)\end{array}$ & (2.5) \\
\hline $\begin{array}{c}\text { Knudsen } \\
\text { dimensionless } \\
\text { number }\end{array}$ & $\mathrm{K}_{\mathrm{n}}=\frac{\bar{\lambda}}{\mathrm{r}_{\text {pore }}}=\frac{\mu_{\mathrm{G}}}{2.81708 \mathrm{P}_{\mathrm{G}}} \sqrt{\frac{\pi \mathrm{RT}}{2 \mathrm{M}} \frac{\varphi}{\mathrm{k}}}$ & (2.6) \\
\hline $\begin{array}{c}\text { The Knudsen } \\
\text { diffusivity, } \\
D_{K}\end{array}$ & $\mathrm{D}_{\mathrm{K}}=\frac{4 \sqrt{\mathrm{k} \varphi}}{2.81708} \sqrt{\frac{\pi \mathrm{RT}}{2 \mathrm{M}}}$ or $\mathrm{D}_{\mathrm{K}}=\frac{\mathrm{kb}}{\mu_{\mathrm{G}}}$ & (2.7) \\
\hline $\begin{array}{c}\text { Energy } \\
\text { Accumulation }\end{array}$ & $\begin{array}{l}\mathrm{M}^{\theta} \\
=(1-\varphi) \int_{\mathrm{T}_{\mathrm{ref}}}^{\mathrm{T}} \rho_{\mathrm{R}} \mathrm{C}_{\mathrm{R}}(\mathrm{T}) \mathrm{dT} \\
+\sum_{\beta=\mathrm{A}, \mathrm{G}, \mathrm{H}}^{\mathrm{n}} \varphi \mathrm{S}_{\beta} \rho_{\beta} \mathrm{U}_{\beta} \\
+\delta_{\psi}^{\mathrm{i}}(1-\varphi) \rho_{\mathrm{R}} \sum_{\mathrm{i}=1}^{\mathrm{N}_{\mathrm{G}}} \mathrm{u}^{\mathrm{i}} \psi^{\mathrm{i}}\end{array}$ & (2.8) \\
\hline Heat Flux & $\begin{aligned} \mathrm{F}^{\theta}=-\overline{\mathrm{k}}_{\theta} \nabla \mathrm{T}+\mathrm{f}_{\sigma} \sigma_{\mathrm{o}} & \nabla \mathrm{T}^{4} \\
& +\sum_{\mathrm{k}=\mathrm{A}, \mathrm{G}} \mathrm{H}_{\beta} \mathrm{F}_{\beta}\end{aligned}$ & (2.9) \\
\hline
\end{tabular}

In Table 1, Equation 2.5, Equation 2.6, and Equation 2.7 the Knudsen diffusion equations are used for ultra-low permeability media (e.g., tight sands and shales). Alternatively, it is also possible to choose turbulent flow (non-Darcian flow) equations or slippage effects 
(Klinkenberg flow: non-Darcian flow) in TOUGH + RealGasBrine. Equation 2.8 and Equation 2.9 are valid for non-isothermal simulations with TOUGH + RealGasBrine. In this study, conventional gas reservoirs are aimed to be studied so Darcy flow is assumed to be valid during numerical simulations with TOUGH + RealGasBrine. a) Viscous Flow

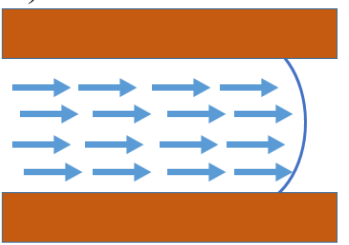

b) Slip Flow

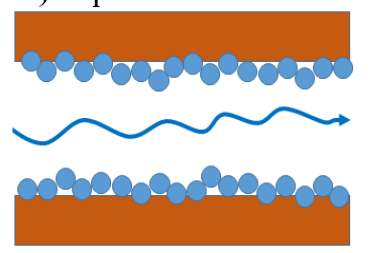

c) Knudsen Flow

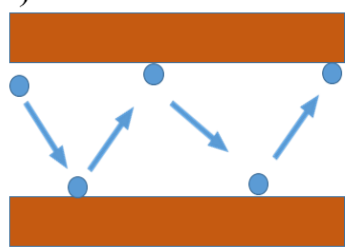

Figure 3. a) Viscous flow if the radius of the flow channels is very large compared to the mean free path of the gas molecules b) Slip flow because of accumulation of gas molecules along pore surface c) Knudsen diffusion or free molecular flow if the radius of the flow channels is very small compared to the mean free path of the gas molecules (Adapted from Ali and Malik [17]).

There are many equations proposed for non-Darcy flow estimations and the details are available in the manual of TOUGH + RealGasBrine [16]. It is possible to simulate isothermally and non-isothermally. For non-isothermal simulations, Equation 2.8 and Equation 2.9 are used. Differently, the heat change due to adsorption or desorption is considered in Equation 2.8 because adsorption and desorption are exothermic and endothermic, respectively. There are many models available calculating other parameters used in the equations in Table 1 such as capillary pressure, relative permeability and other thermophysical properties as function of primary variables. Similar to all TOUGH+ applications, the space and time discretization, the Newton-Raphson method, and the use of the Jacobian matrix solution in the fully implicit solution are used in TOUGH + RealGasBrine [16].

\section{Results and Discussion}

TTP method is commonly used to open perforations in gas zones. It is practical to open perforations in multilayered gas reservoirs. Even without rigs, it is possible to perforate gas zones with TTP method. The wellbore connects all perforation zones in this method. Generally, perforations of multiple zones start from deeper zone to upper zone. After perforating a gas zone in the lower section, the upper possible gas zone(s) can be perforated according to the results of well logging analysis.
However, the wrong analysis of the upper interval might affect gas production from the gas zone in the lower section negatively. If the upper zone is highly saturated with water, water flows through the gas zone in the lower section just after the perforation of the upper zone. This causes the sudden reduction in gas production rate of this well. While transferring workover rig to the well to stop this water flux, water keeps flowing through the gas zone in the lower section. It is possible to isolate the upper perforations producing water by well completion operations. However, until these operations, important amount of water invades the gas zone. There are not any numerical studies analyzing the effect of water invasion to gas zones after through tubing perforations (TTP) by numerical simulations so this topic was investigated in this study.

Table 2. The parameters used for numerical simulations by using TOUGH+RealGasBrine for the simulations.

\begin{tabular}{|c|c|c|}
\hline Parameter & Gas Zone & $\begin{array}{l}\text { Water } \\
\text { Zone }\end{array}$ \\
\hline Reservoir Net Thickness, m & 10 & 10 \\
\hline Reservoir Radius, $\mathrm{m}$ & 250 & 250 \\
\hline Reservoir Temperature, ${ }^{\circ} \mathrm{C}$ & $70^{\circ} \mathrm{C}$ & $70^{\circ} \mathrm{C}$ \\
\hline Gas Composition & $100 \% \mathrm{CH}_{4}$ & $100 \% \mathrm{CH}_{4}$ \\
\hline $\begin{array}{l}\text { Aqueous and Gas Saturation, } \\
\%\end{array}$ & $\begin{array}{l}\mathrm{S}_{\mathrm{A}}: 20 \\
\mathrm{~S}_{\mathrm{G}}: 80\end{array}$ & $\begin{array}{l}\mathrm{S}_{\mathrm{A}}: 80 \\
\mathrm{~S}_{\mathrm{G}}: 20\end{array}$ \\
\hline Porosity, $\%$ & 30 & 30 \\
\hline Grain Density, $\mathrm{kg} / \mathrm{m}^{3}$ & 2600 & 2600 \\
\hline $\begin{array}{l}\text { Dry Thermal Conductivity, } \\
\mathrm{W} / \mathrm{m} . \mathrm{K}\end{array}$ & 0.5 & 0.5 \\
\hline $\begin{array}{l}\text { Wet Thermal Conductivity, } \\
\text { W/m.K }\end{array}$ & 3.1 & 3.1 \\
\hline $\begin{array}{l}\text { Salt mass fraction wt. } \% \text { in } \\
\text { aqueous phase }\end{array}$ & 0.1 & 0.1 \\
\hline $\begin{array}{l}\text { Capillary Pressure Model } \\
\text { Parameters of van Genuchten } \\
\text { [19] }\end{array}$ & $\begin{array}{c}\text { SirA: } 0.149 \\
\lambda: 0.45 \\
\mathrm{P}_{0}: 2 \times 10^{3} \\
\quad \mathrm{~Pa}\end{array}$ & $\begin{array}{l}\text { SirA: } 0.149 \\
\lambda: 0.45 \\
\mathrm{P}_{0}: 2 \times 10^{3} \\
\mathrm{~Pa}\end{array}$ \\
\hline $\begin{array}{l}\text { Relative Permeability Model } \\
\text { Parameters of Stone [20] }\end{array}$ & $\begin{array}{l}\mathrm{S}_{\mathrm{irA}}: 0.15 \\
\mathrm{~S}_{\mathrm{irG}}: 0.01 \\
\text { n: } 4\end{array}$ & $\begin{array}{c}\mathrm{S}_{\mathrm{irA}}: 0.15 \\
\mathrm{~S}_{\mathrm{irG}}: 0.01 \\
\text { n: } 4\end{array}$ \\
\hline
\end{tabular}

For the numerical simulations, TOUGH + RealGasBrine was chosen. Table 2 summarizes the parameters for the numerical simulations held with TOUGH + RealGasBrine for the hypothetical gas zone and water zone. For capillary pressure parameters and relative permeability parameters, the values which are widely used in literature were selected. The gas and water saturation of gas zone in the lower section are $80 \%$ and $20 \%$, respectively. It was assumed that impermeable shale zone separates water zone and gas zone as seen in Figure 4-b. Figure 4-a indicates the distribution grids in the half section of cylindrical reservoir ( $250 \mathrm{~m}$ of radius). The grids are dense in gas zone and water zone especially near wellbore because these zones were analyzed in this study. The grids along $\mathrm{z}$ axis are cartesian. The number of the grids in gas zone and water zone is 20 each with $0.5 \mathrm{~m}$ thickness. 10 coarse grids with $5 \mathrm{~m}$ were distributed in shale zone along $\mathrm{z}$ axis because this zone is impermeable and it is not the interest of this study. 
a)

Wellbore

b)

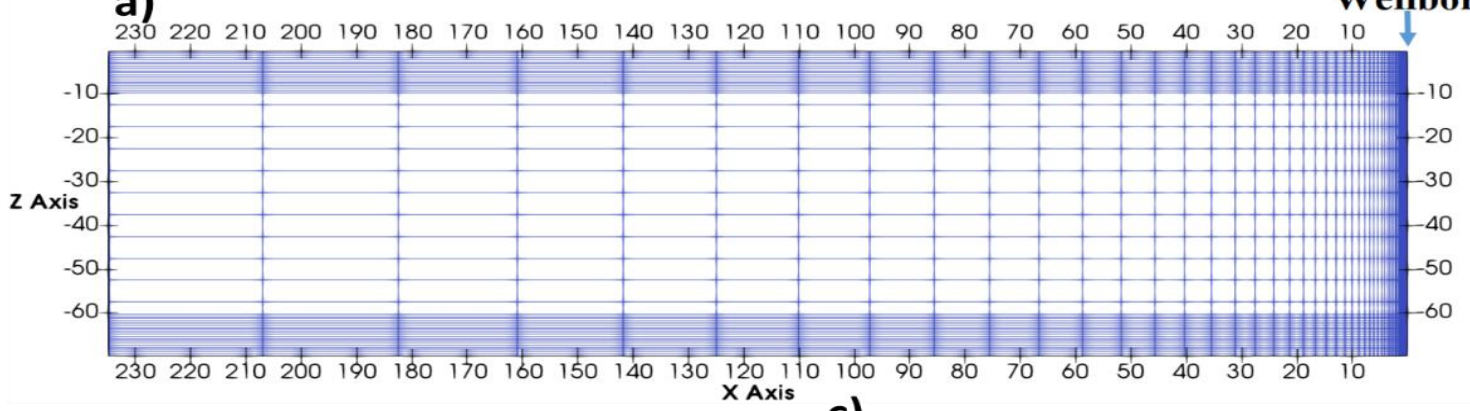

X Axis C)
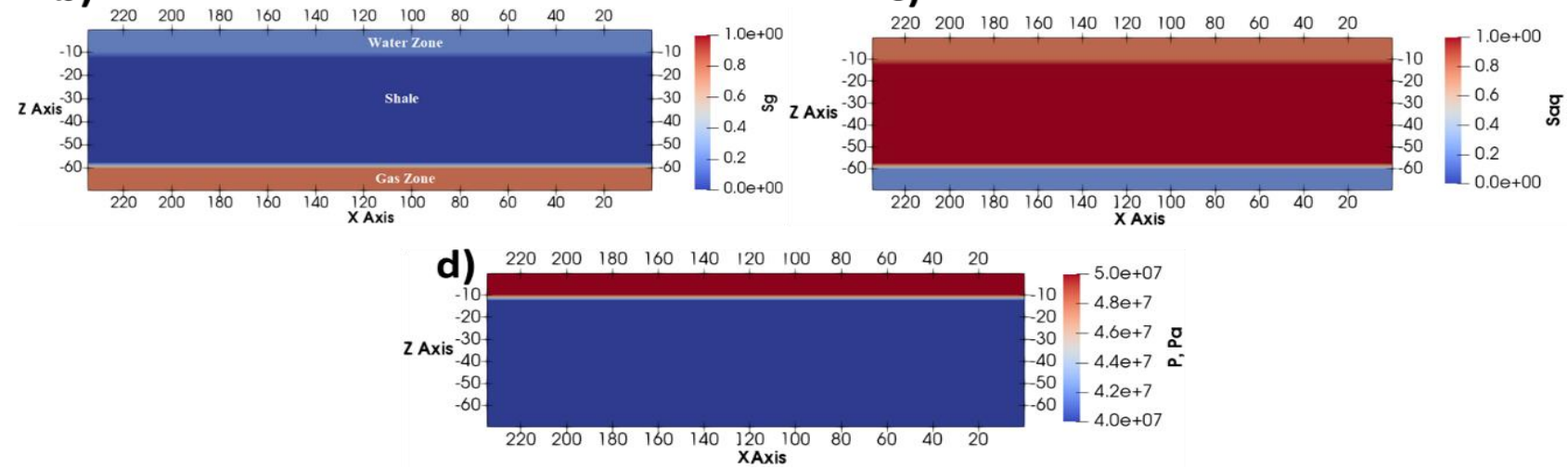

Figure 4. a) Grid structure of the half of the cylindrical reservoir b) Initial gas saturation in the hypothetical reservoir c) Initial aqueous saturation in the hypothetical reservoir d) Initial pressure distribution in the hypothetical reservoir.

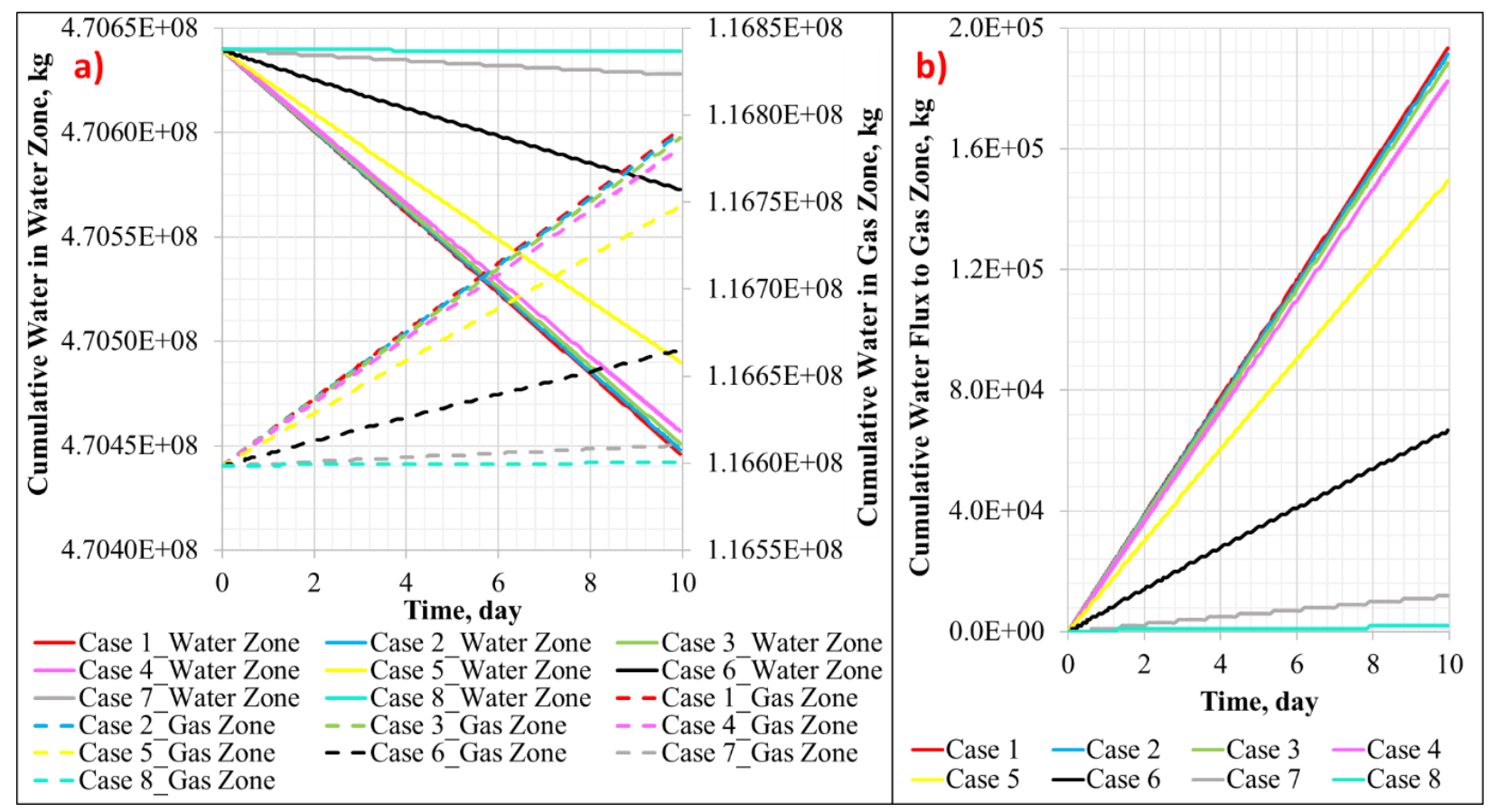

Figure 5. a) Cumulative water in water zone and gas zone after the opening of the perforations in water zone b) Cumulative water flux to gas zone from water zone after the opening of the perforations in water zone for Case 1, Case 2, Case 3, Case 4, Case 5, Case 6, Case 7 and Case 8. 
The grids (250 grids) along $\mathrm{x}$ axis (radial) in Figure 4-b are distributed logarithmically. Figure 4-b and Figure 4c show gas and water saturations in the hypothetical reservoir. In order to understand the effect of permeability on water flux from water zone to gas zone, the numerical simulations with different permeability cases in Table 3 were conducted by using TOUGH + RealGasBrine. Shale zone in Figure 4-b was assumed as impermeable for all simulations in this study.

Table 3. The cases with different permeability values for gas zone and water zone.

\begin{tabular}{|c|c|c|c|c|c|}
\hline \multirow[t]{2}{*}{ Case } & \multicolumn{2}{|c|}{$\begin{array}{l}\text { Permeability Gas } \\
\text { and Water Zone }\end{array}$} & $\begin{array}{c}\text { Pressure } \\
\text { in Gas } \\
\text { Zone and } \\
\text { Shale } \\
\text { Zone }\end{array}$ & $\begin{array}{c}\text { Pressure } \\
\text { in Water } \\
\text { Zone }\end{array}$ & \multirow{2}{*}{$\begin{array}{c}\text { Salt } \\
\text { mass in } \\
\text { the } \\
\text { aqueous } \\
\text { phase } \\
\text { Wt. \% }\end{array}$} \\
\hline & $\mathbf{m D}$ & $\mathbf{m}^{2}$ & MPa & MPa & \\
\hline 1 & 1000 & $9.869 \times 10^{-13}$ & & & \\
\hline 2 & 500 & $4.935 \times 10^{-13}$ & & & \\
\hline 3 & 250 & $2.467 \times 10^{-13}$ & & & \\
\hline \multirow[t]{2}{*}{4} & 100 & $9.869 \times 10^{-14}$ & & & \\
\hline & & & 4 & 6 & 1 \\
\hline 5 & 10 & $9.869 \times 10^{-15}$ & & & \\
\hline 6 & 1 & $9.869 \times 10^{-16}$ & & & \\
\hline 7 & 0.1 & $9.869 \times 10^{-17}$ & & & \\
\hline 8 & 0.01 & $9.869 \times 10^{-18}$ & & & \\
\hline
\end{tabular}

Numerical simulations with TOUGH + RealGasBrine for the cases in Table 3 were held for the hypothetical reservoir in Figure 4. Initially, the perforations in gas zone were open. Then, the upper zone was perforated because these zones were predicted as the possible gas zone. However, this zone is highly saturated water zone as seen in Figure 4-c. The pressure in the water zone is 6 $\mathrm{MPa}$ but the pressure in gas zone is $4 \mathrm{MPa}$. This pressure difference increased the water influx from water zone to gas zone. Figure 5 shows the main results of the cases in Table 3. It is possible to observe the change in the cumulative water in water zone and gas zone in Figure 5a. The cumulative water in water zone decreases but the cumulative water amount in gas zone increases. This is due to the water influx from upper zone to lower zone. This influx decreases as the permeability of water and gas zone decreases. This can be seen clearly in Figure 5-b. Hence, workover rig should start to well completion operations as quick as possible to stop this water influx. Mainly, water zone might be cemented or sealed with other completion methods to avoid any negative effects to gas zone. However, until this time, certain amount of water will move from water zone to gas zone. Even after isolating water zone with well completion operations, the effect of this flux on gas production in gas zone is not ignorable and it is aimed to prove this by numerical simulations.

Figure 6 illustrates the water influx (water saturation distribution: $S_{\text {aq }}$ ) from water zone to gas zone after perforation with TTP method when the permeability of water and gas zone is $1000 \mathrm{mD}(1 \mathrm{D})$.

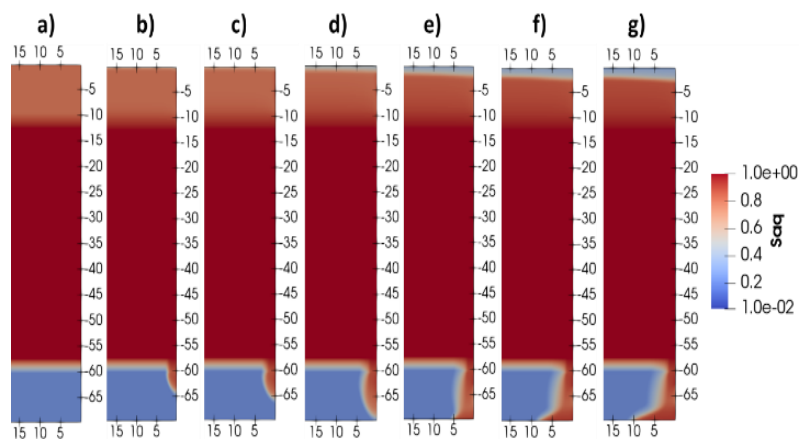

Figure 6. Water saturation distribution in Case 1: a) the initial conditions before perforating water zone b) water influx to gas zone within 0.5 day after perforating water zone c) water influx to gas zone within 1 day after perforating water zone d) water influx to gas zone within 2.5 days after perforating water zone e) water influx to gas zone within 5 days after perforating water zone f) water influx to gas zone within 7.5 days after perforating water zone g) water influx to gas zone within 10 days after perforating water zone.

Water started to invade gas zone near wellbore as seen in Figure 6-b after 0.5 day as the perforation of water zone was completed. With time, most of water was collected in the bottom of gas reservoir due to gravity as seen in Figure 6-f. Then, water front went further into the bottom of gas reservoir in Figure 6-g. The quick settlement of water in the bottom of gas reservoir is due to high permeability of gas reservoir. Figure 6 clearly shows that if water zone is not isolated quickly, high amount of water will move to gas reservoir. This will decrease gas production in long term. For this reason, wellhead pressures and gas production rates of gas wells should be monitored carefully to observe similar water fluxes. If this is observed earlier, the negative effect of water influx to gas zone will be minimum. As shown in Figure 6-b, water flux was observed in the top 5-meter of gas zone and water front was nearly $2.5 \mathrm{~m}$ from wellbore within 0.5 day. However, water invaded $10 \mathrm{~m}$ thick gas reservoir and water front was approximately $12 \mathrm{~m}$ from wellbore within 10 days in Figure 6-g.

In Case 5 simulation, the permeability of water and gas zone was selected as $10 \mathrm{mD}$. It is possible to observe water influx to gas zone after perforating water zone in Figure 7. Compared to Case 1 in Figure 6, water in Figure 7 could not penetrate inside gas zone easily because of lower permeability of Case 5. Moreover, water could not settle in the bottom of gas reservoir in Case 5 as in Case 1. Lower permeability of Case 5 is the main reason of 
this. Water fronts in Case 5 within 0.5 day and 10 days were $2 \mathrm{~m}$ and $6 \mathrm{~m}$, respectively. This indicates that the amount of water flux to gas zones after perforating wrong zone including highly saturated water zone depends on the permeability of porous media. Figure 8 illustrates the behavior of water flux to gas zone in Case 8 when the permeability of porous media is very low $(0.1 \mathrm{mD})$. Even after 10 days, water front was less than $0.5 \mathrm{~m}$. All these results indicated that water invasion in gas zone increases when the permeability of gas zone increases. Numerical simulations are important tools to understand the effect of water flux to gas zone from upper zone. By using numerical simulations with TOUGH + RealGasBrine, it is possible to understand the degree of water invasion. Furthermore, the simulation results provide to predict the effect of water invasion on gas production from gas zone in a long term.

From Case 1 to Case 8, it was assumed that the pressure difference between water zone and gas zone is $2 \mathrm{MPa}$. The effect of permeability was investigated in these cases. Similarly, it is essential to analyze the effect of pressure difference between water zone and gas zone. Thus, the numerical simulations with various pressure differences between these two zones were held when the permeability of water zone and gas zone is $100 \mathrm{mD}$. These cases are listed in Table 4. Other important parameters of these numerical simulations are listed in Table 2.

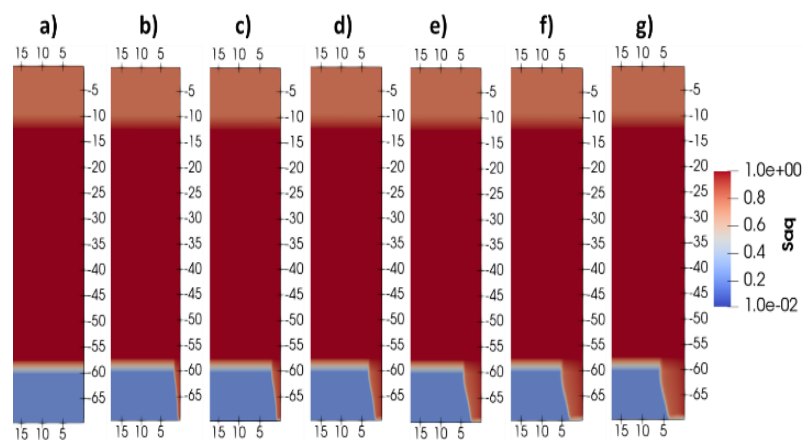

Figure 7. Water saturation distribution in Case 5: a) the initial conditions before perforating water zone b) water influx to gas zone within 0.5 day after perforating water zone c) water influx to gas zone within 1 day after perforating water zone d) water influx to gas zone within 2.5 days after perforating water zone e) water influx to gas zone within 5 days after perforating water zone f) water influx to gas zone within 7.5 days after perforating water zone g) water influx to gas zone within 10 days after perforating water zone.

The results of the numerical simulations for the cases in Table 4 are shown in Figure 9. When the pressure differences between water zone and gas zone decreased, the cumulative water influx to gas zone from water zone decreased in Figure 9. The visualization of these water fluxes at different cases in Table 4 is important to understand the effect of pressure differences on water invasion in gas zone. Figure 10 indicates the water saturation distributions in the hypothetical reservoir within 10 days after perforating water zone when the permeability is $100 \mathrm{mD}$. As pressure difference between water zone and gas zone was $30 \mathrm{MPa}$, the water front was approximately $8 \mathrm{~m}$ in Figure 10 -a (Case 9). On the other hand, this water front was less than $0.5 \mathrm{~m}$ when pressure difference between water zone and gas zone was $0 \mathrm{MPa}$ in Figure 10-f (Case 14). In Case 14, the gravity difference caused the water influx even if the pressure different was nearly zero because water zone is in the upper part.

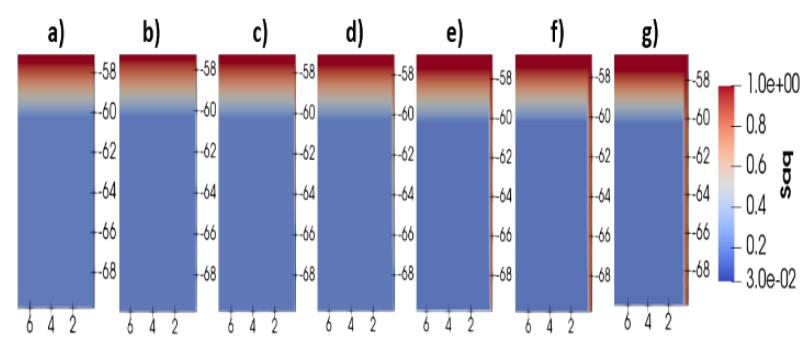

Figure 8. Water saturation distribution in Case 8: a) the initial conditions before perforating water zone b) water influx to gas zone within 0.5 day after perforating water zone c) water influx to gas zone within 1 day after perforating water zone d) water influx to gas zone within 2.5 days after perforating water zone e) water influx to gas zone within 5 days after perforating water zone $\mathbf{f}$ ) water influx to gas zone within 7.5 days after perforating water zone g) water influx to gas zone within 10 days after perforating water zone.

Table 4. The cases with various pressure differences when the permeability of gas zone and water zone is 100 $\mathrm{mD}$.

\begin{tabular}{cccccc}
\hline Case & $\begin{array}{c}\text { Pressure } \\
\text { in Gas } \\
\text { Zone } \\
\text { and } \\
\text { Shale } \\
\text { Zone }\end{array}$ & $\begin{array}{c}\text { Pressure } \\
\text { in } \\
\text { Water } \\
\text { Zone }\end{array}$ & $\begin{array}{c}\text { Pressure } \\
\text { Difference }\end{array}$ & Permeability & $\begin{array}{c}\text { Salt } \\
\text { mass in } \\
\text { the } \\
\text { aqueous } \\
\text { phase }\end{array}$ \\
\cline { 2 - 4 } MPa & MPa & MPa & mD & Wt. \% \\
\hline $\mathbf{9}$ & 40 & 70 & 30 & & \\
\hline $\mathbf{1 0}$ & 40 & 60 & 20 & & \\
\hline $\mathbf{1 1}$ & 40 & 50 & 10 & & \\
\hline $\mathbf{1 2}$ & 40 & 45 & 5 & & \\
\hline $\mathbf{1 3}$ & 40 & 41 & 1 & & \\
\hline $\mathbf{1 4}$ & 40 & 40 & 0 & & \\
\hline
\end{tabular}

From Case 15 to Case 20, the effect of water salinity in water zone on water flux through gas zone was investigated by numerical simulations with TOUGH + RealGasBrine. The parameters selected for these simulations are listed in Table 2 and Table 5. Figure 11 shows the cumulative water flux to gas zone from water zone after the opening of the perforations in water zone for Case 15, Case 16, Case 17, Case 18, Case 19 and Case 20. It is obviously seen that the increase in the salinity of water in water zone decreased the amount of water flux to gas zone. The main reason of this is that water viscosity increases with increasing salinity and this reduces water front length. 


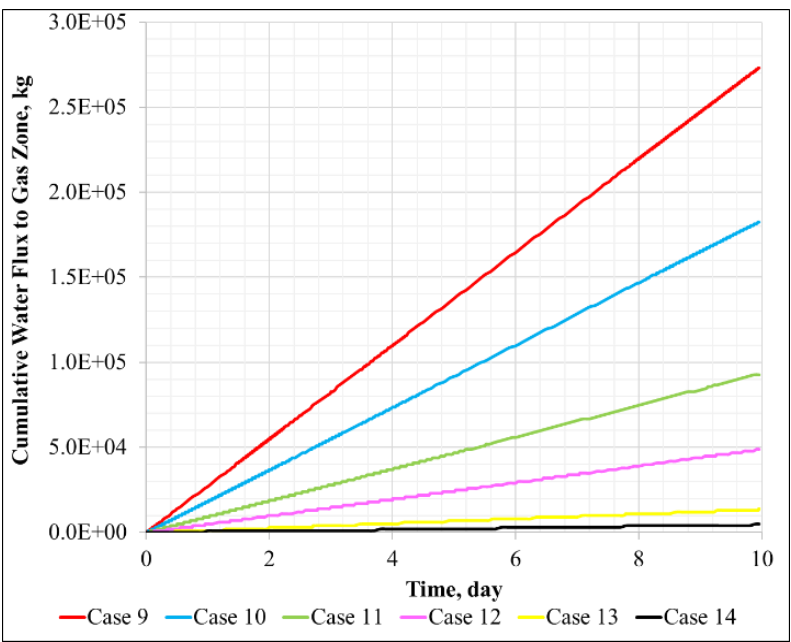

Figure 9. Cumulative water flux to gas zone from water zone after the opening of the perforations in water zone for Case 9, Case 10, Case 11, Case 12, Case 13 and Case 14.

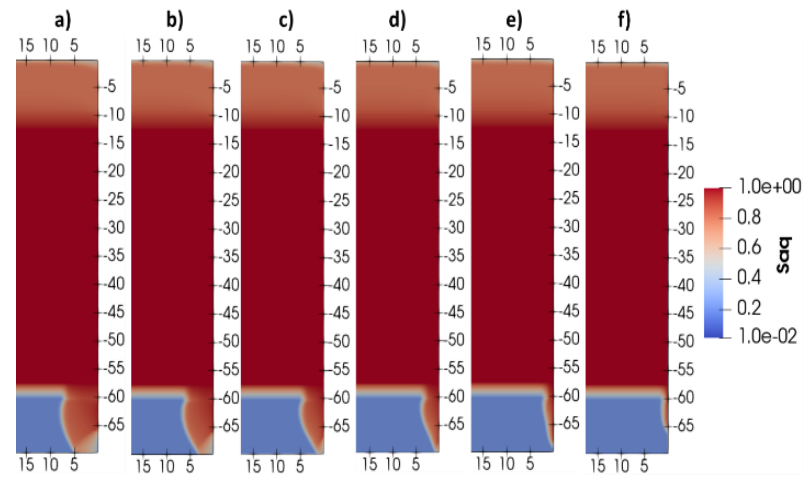

Figure 10. Water saturation distribution in a) Case 9 b) Case 10 c) Case 11 d) Case 12 e) Case 13 f) Case 14 within 10 days after perforating water zone as the permeability is $100 \mathrm{mD}$.

Table 5. The cases with different water salinity in water zone when the permeability of gas zone and water zone is $100 \mathrm{mD}$

\begin{tabular}{|c|c|c|c|c|c|}
\hline Case & $\begin{array}{c}\text { Water } \\
\text { Salinity } \\
\text { in } \\
\text { Water } \\
\text { Zone }\end{array}$ & $\begin{array}{c}\text { Water } \\
\text { Salinity } \\
\text { in Gas } \\
\text { Zone }\end{array}$ & Permeability & $\begin{array}{c}\text { Pressure } \\
\text { in Gas } \\
\text { Zone } \\
\text { and } \\
\text { Shale } \\
\text { Zone }\end{array}$ & $\begin{array}{c}\text { Pressure } \\
\text { in } \\
\text { Water } \\
\text { Zone }\end{array}$ \\
\hline & Wt. \% & Wt. \% & $\mathbf{m D}$ & MPa & MPa \\
\hline 15 & 0 & \multirow{5}{*}{1} & \multirow{5}{*}{100} & \multirow{5}{*}{40} & \multirow{5}{*}{60} \\
\hline 16 & 1 & & & & \\
\hline $\begin{array}{l}17 \\
18\end{array}$ & $\begin{array}{l}5 \\
10\end{array}$ & & & & \\
\hline 19 & 20 & & & & \\
\hline 20 & 27.2 & & & & \\
\hline
\end{tabular}

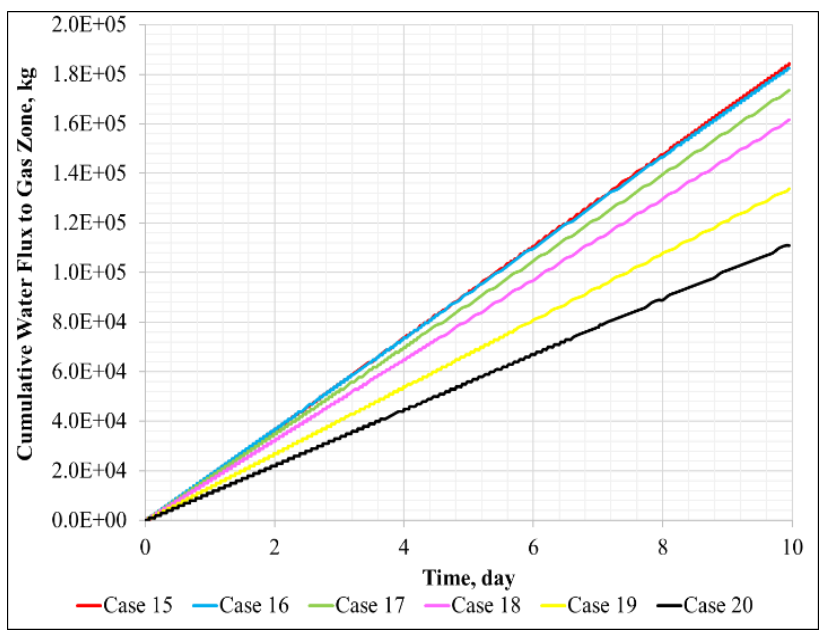

Figure 11. Cumulative water flux to gas zone from water zone after the opening of the perforations in water zone for Case 15, Case 16, Case 17, Case 18, Case 19 and Case 20.

Figure 12 illustrates water saturation distribution in Case 15, Case 16, Case 17, Case 18, Case 19 and Case 20 within 10 days after perforating water zone as the permeability is $100 \mathrm{mD}$. Water reached to approximately $7 \mathrm{~m}$ inside gas zone in Figure 12-a for Case 15 within 10 days. However, this length decreased below $5 \mathrm{~m}$ in Case 20 as shown in Figure 12-f. The main reason of $27.2 \%$ wt. salinity in water and it increased the viscosity. Although the effect of water salinity on water influx is not as high as this in Case 1-Case 8 for different permeability, it is important to make correct prediction of water distribution in gas zone after water flux.

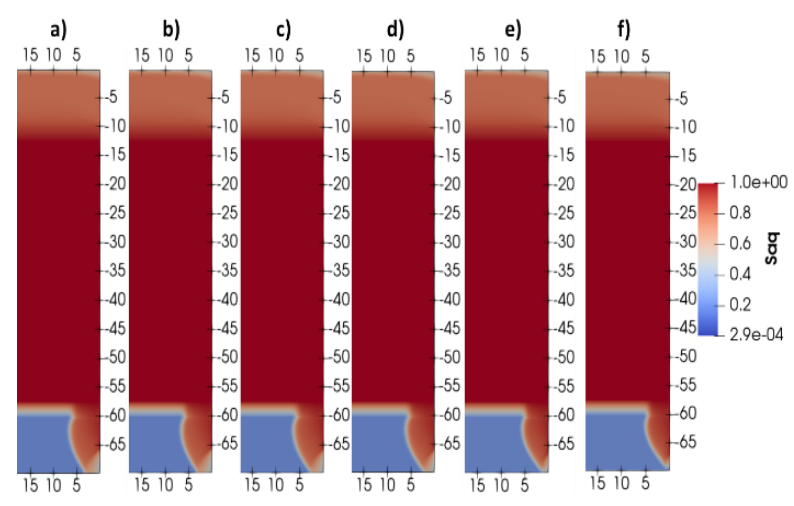

Figure 12. Water saturation distribution in a) Case 15 b) Case 16 c) Case 17 d) Case 18 e) Case 19 f) Case 20 within 10 days after perforating water zone as the permeability is $100 \mathrm{mD}$.

According to the simulations from Case 1 to Case 20, permeability, pressure difference, and water salinity affect the water invasion behavior and water flux amount to gas zone significantly. After recognizing high water influx from newly perforated zone, it is important to initiate workover operations. Workover rig is essential to isolate the upper zone including water with higher pressures. When this is accomplished, final water distribution in gas zone should be predicted in order to 
make a plan for gas production from gas zone. The duration of water flux to gas zone is crucial to determine the latest water saturation distribution in gas zone. For this purpose, gas production without any water invasion and gas production after water invasion from upper water zone for 0.5 day, 1 day, 2.5 days, 5 days and 10 days were simulated for Case 1, Case 4 and Case 19. Figure 6-a shows the water distribution in gas zone before perforating upper zone for Case 1. Similarly, these distributions were shown in Figure 6-b, Figure 6-c, Figure 6-d, Figure 6-e and Figure 6-f within 0.5 day, 1 day, 2.5 days, 5 days, 7.5 days, and 10 days, respectively after perforating water zone in the upper section. Hence, if water zone is isolated in a certain time, its effect on gas production varies depending on the duration of this time. Figure 13 shows gas production simulations after these completion times for Case 1. Figure 13-a and Figure 13b show the cumulative gas production and cumulative water production from gas zone at a constant production pressure of $5 \mathrm{MPa}$ for Case 1 . Without any water flux to gas zone (original case), gas production is highest as indicated in Figure 13-a. In Figure 13-b, it is clearly seen that water production is minimum. Water saturation is 20 $\%$ and gas saturation is $80 \%$ in gas zone. The water production from gas zone is not high because irreducible water saturation $\left(\mathrm{S}_{\mathrm{irA}}\right)$ in Table 2 is $15 \%$. However, water production from gas zone increases significantly if gas zone is prone to water flux from water zone in a longer time as in Figure 13-b. For instance, water production increased 2 times compared to the original case if gas zone is prone to water flux for 10 days. Furthermore, this water invasion retards gas production in Figure 13-a. All these simulation results show that the wrong evaluation of water zone as gas zone and its perforation with TTP method caused water flux to gas zone and affected gas production and water production from gas zone significantly. Thus, the well logging analysis and the selection of perforation method are crucial because the mistakes in the designs cause gas production decline and water production increase.

Figure 14-a and Figure 14-b show the cumulative gas production and cumulative water production from gas zone at a constant production pressure of $5 \mathrm{MPa}$ for Case 4. The difference of Case 4 from Case 1 is the permeability of water zone and gas zone in Table 3 . Similar to Figure 13, gas production from gas zone was retarded when gas zone was prone to water flux coming from upper perforations until isolation of water zone with workover operations. Water production from gas zone was highest for 10 day-water flux from water zone to gas zone as seen in Figure 14-b.

Different than Case 4 and Case 9, the salinity in water zone in Case 19 is higher in Table 5. The duration of water flux to gas zone until the isolation of upper water zone is important because when this duration increases, much water moves inside gas zone. As seen in Figure 15a and Figure 15-b, water production is not very high compared to this value in Figure 14-b for Case 4. The main reason of this is that higher viscosity and higher density of more saline water in Case 19 in Figure 15. Figure 16 indicates the change in water saturation distribution for Case 4 with production at a constant pressure of $5 \mathrm{MPa}$ if gas zone was prone to water flux for 10 days, 5 days, 1 day and 0.5 day, respectively. After isolating water zone, gas production from gas zone started but even in long term (200 days) it is possible to see the remarks of previous water flux in water saturation as shown in Figure 16. However, if water flux is observed and water zone is isolated early, the negative effect of water flux is kept minimum in Figure 16-d.

Figure 17 indicates the cumulative gas production from gas zone and the cumulative water production from gas zone for Case 4 when gas zone was prone to water flux for 10 days at different production pressures $(2.5 \mathrm{MPa}, 5$ $\mathrm{MPa}, 7.5 \mathrm{MPa}$ and $10 \mathrm{MPa})$. As production pressure decreases, gas production and water production increases. However, fast production did not remove the remarks of water flux from water zone as seen in Figure 18.

\section{Conclusion}

In this study, the effect of water flux to gas zone after through tubing perforations (TTP) by using TOUGH + RealGasBrine simulator was investigated. A multilayered hypothetical reservoir was chosen for numerical simulations by TOUGH + RealGasBrine. Initially, gas zone in the bottom of the reservoir was perforated with TTP method and then upper zone was perforated. However, in the upper zone, higher water saturation was detected and water in the upper zone moved through gas zone. This affected gas production and water production behavior negatively. TOUGH + RealGasBrine simulator provides to make simulations in different scenarios. In this study, the following conclusion remarks were obtained during the simulations with different cases:

- Initially, the simulations for Case 1 to Case 8 were held at different permeabilities. At very high permeability values, water flux into gas zone was highest. Moreover, most of water was collected in the bottom of gas zone when the permeability was very high. The reduction in permeability changed the behavior of water invasion to gas zone and also the amount of water moved from water zone to gas zone decreased as well. For this reason, it is important to have the permeability parameters of both water zone and gas zone.

- When pressure difference between water zone and gas zone increases, the amount of water flux from water zone to gas zone increased significantly. However, even the pressure in water zone and gas zone are close to each other, water moves though gas zone due to higher gravity of water.

- Salinity in water zone affected the penetration of water through gas zone because its viscosity increased with salinity. 
Celal Bayar University Journal of Science

Volume 15, Issue 1, 2019, p 99-113

Doi: $10.18466 /$ cbayarfbe.483578

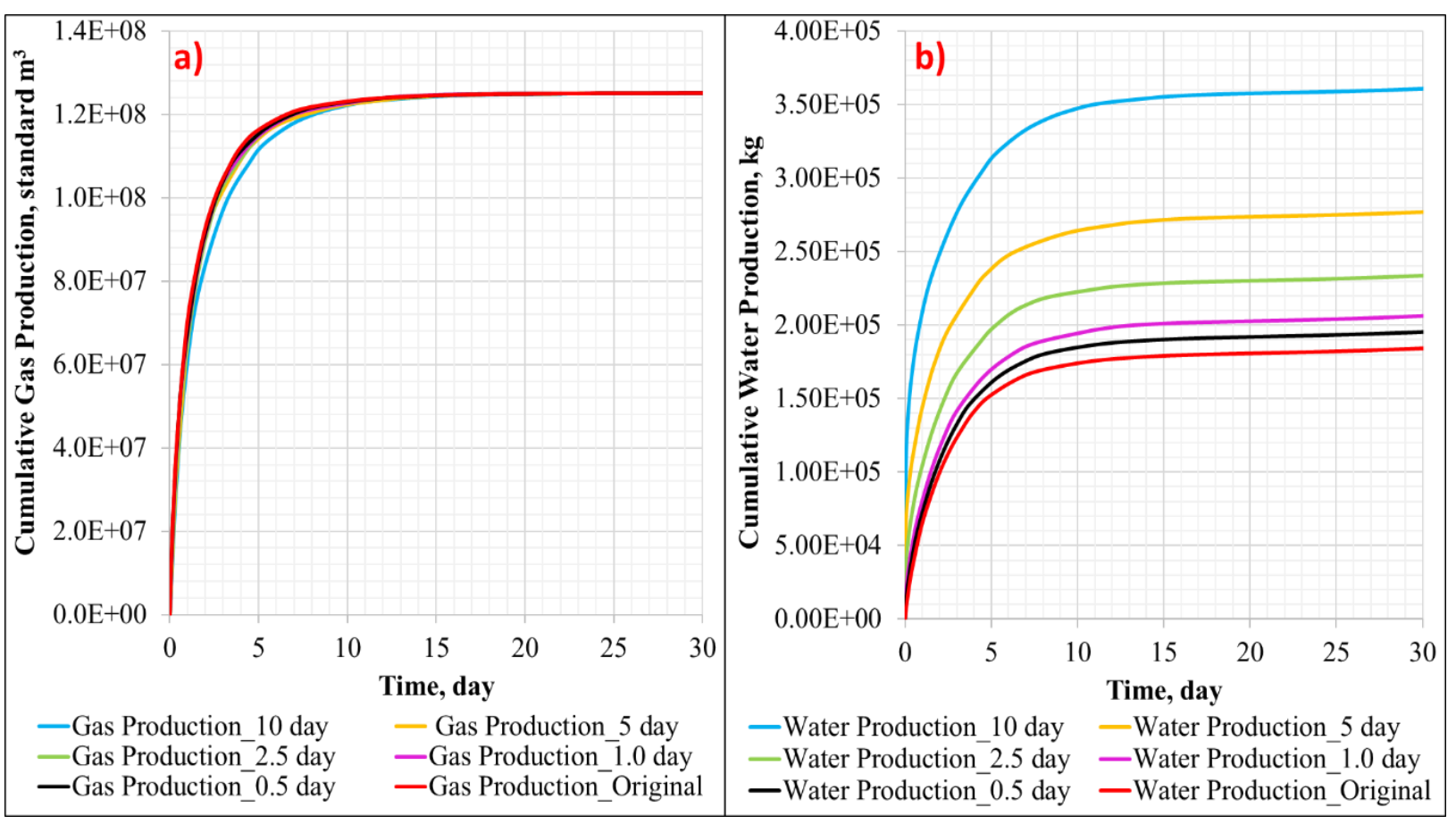

Figure 13. a) Cumulative gas production from gas zone b) Cumulative water production from gas zone for Case 1 at a constant production pressure of $5 \mathrm{MPa}$.

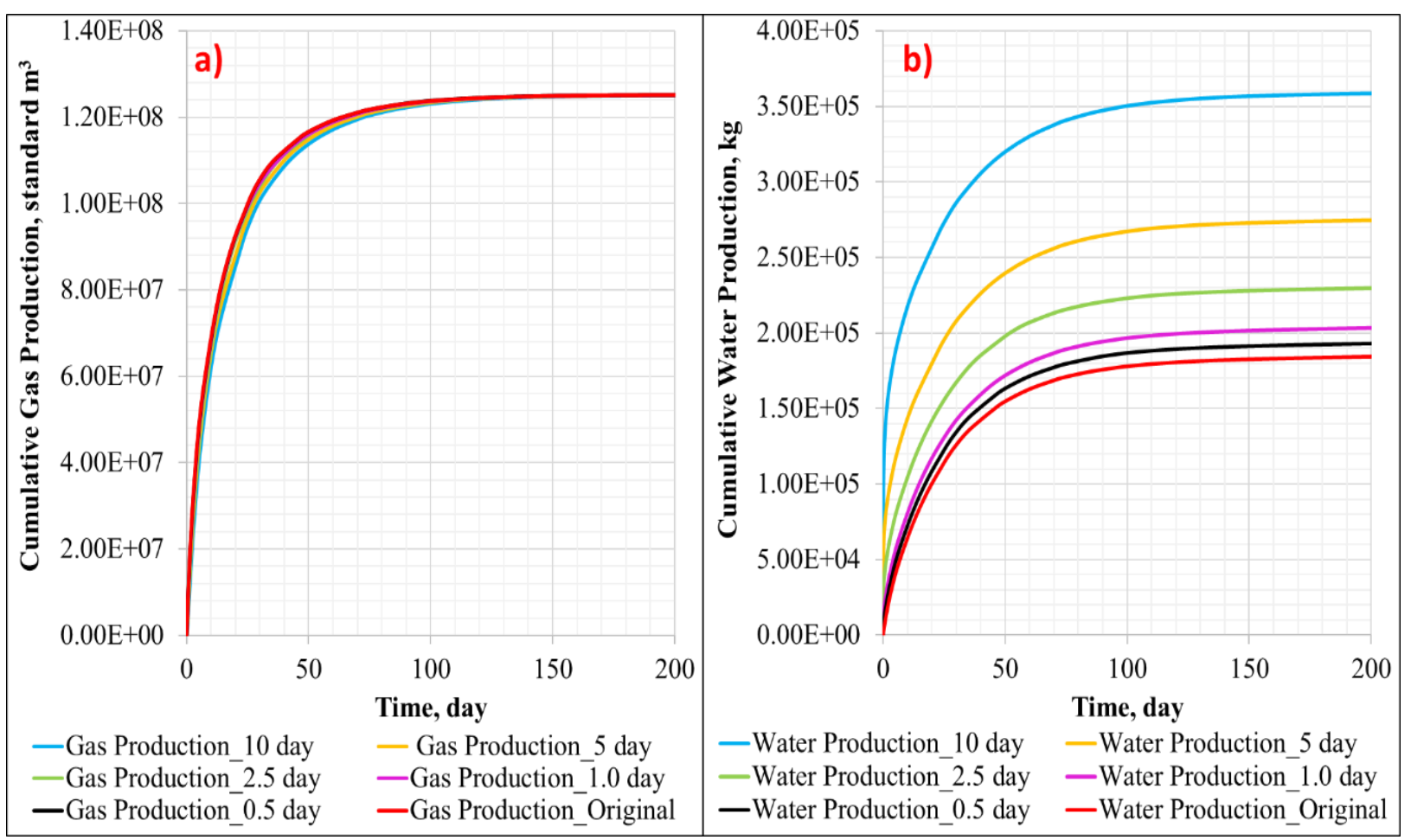

Figure 14. a) Cumulative gas production from gas zone b) Cumulative water production from gas zone for Case 1 at a constant production pressure of $5 \mathrm{MPa}$. 


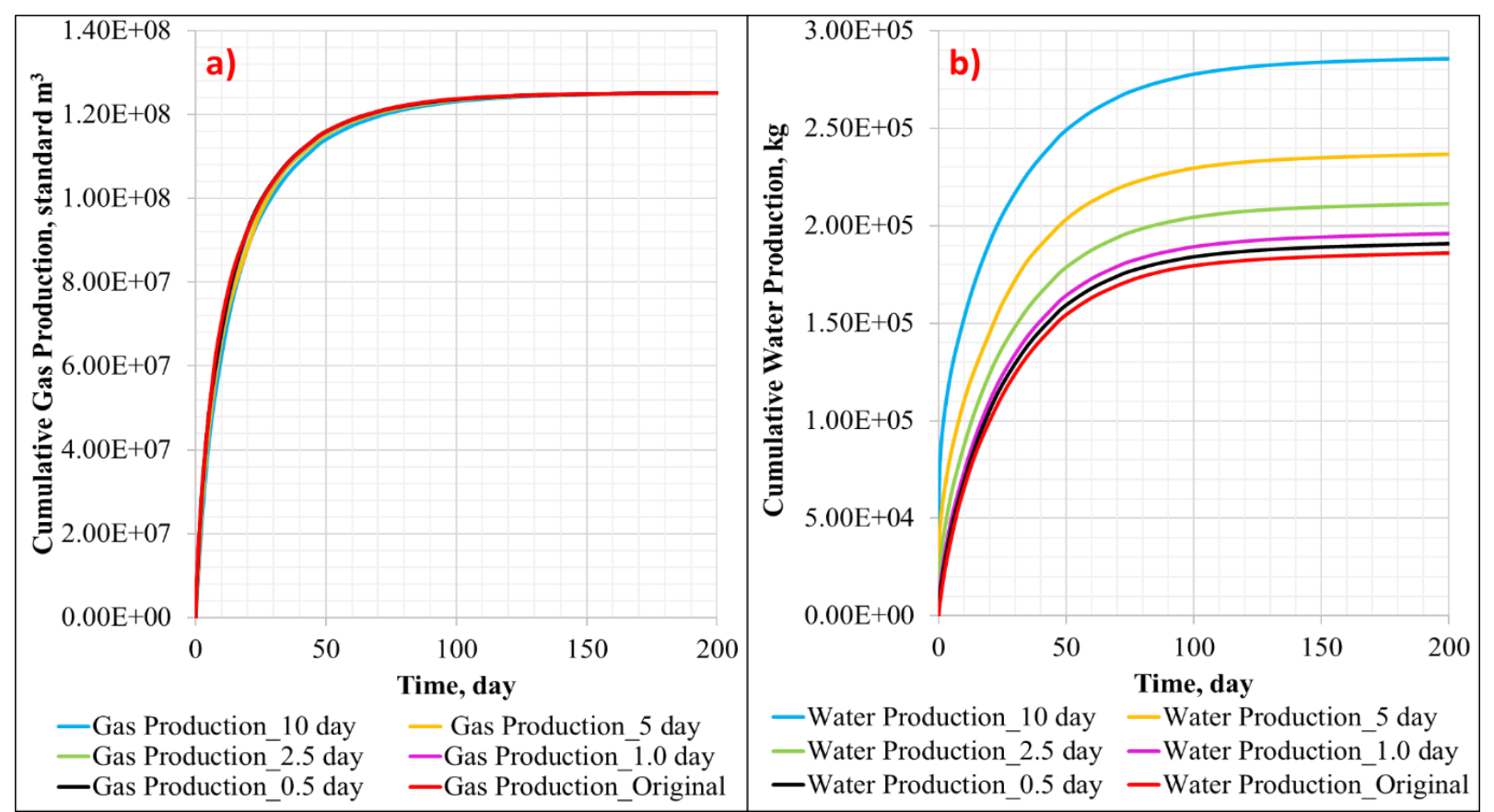

Figure 15. a) Cumulative gas production from gas zone b) Cumulative water production from gas zone for Case 19 at a constant production pressure of $5 \mathrm{MPa}$.

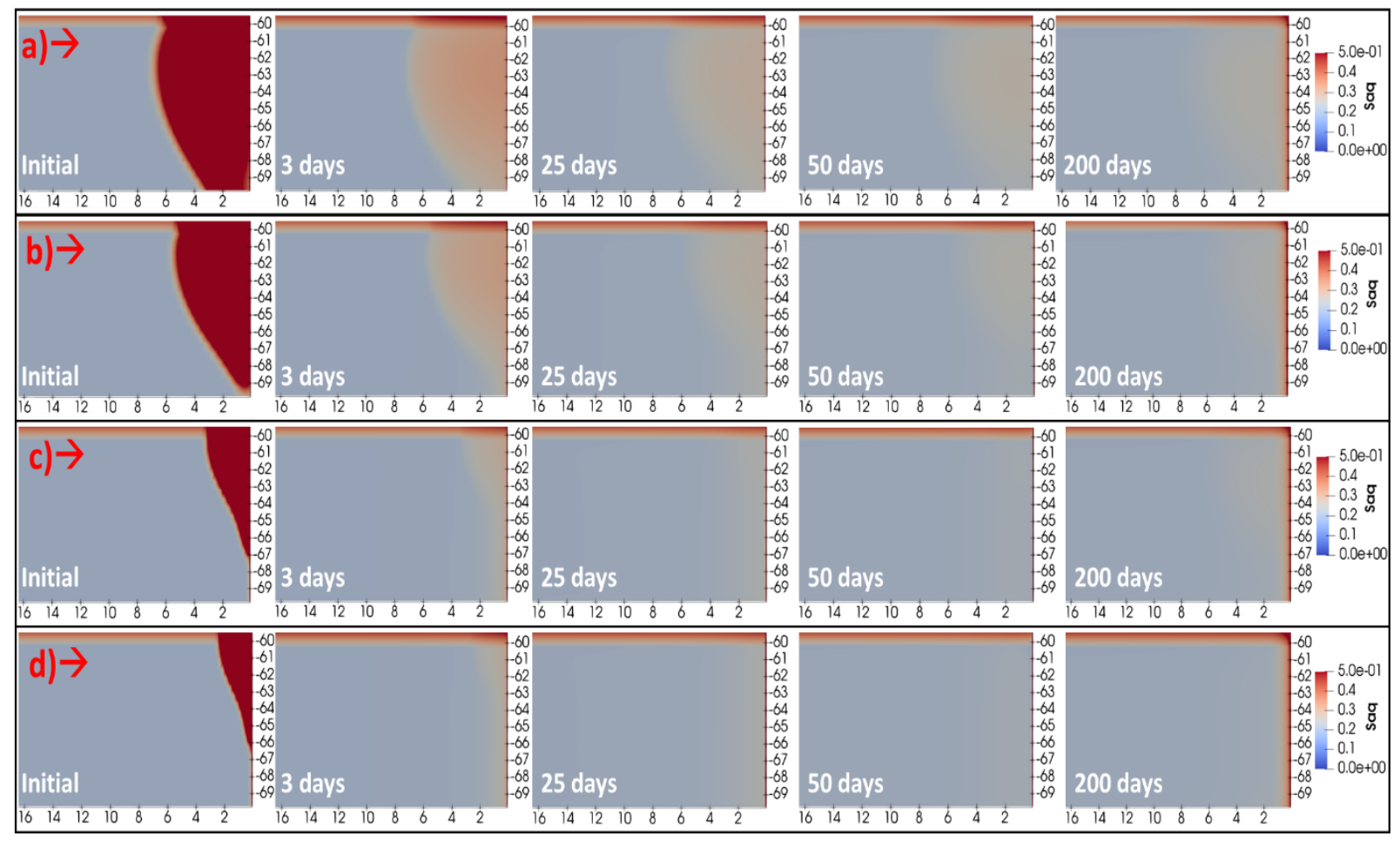

Figure 16. The change in water saturation distribution for Case 4 with production at a constant pressure of $5 \mathrm{MPa}$ a) if gas zone was prone to water flux for 10 days $\mathbf{b}$ ) if gas zone was prone to water flux for 5 days $\mathbf{c}$ ) if gas zone was prone to water flux for 1-day d) if gas zone was prone to water flux for 0.5 day. 


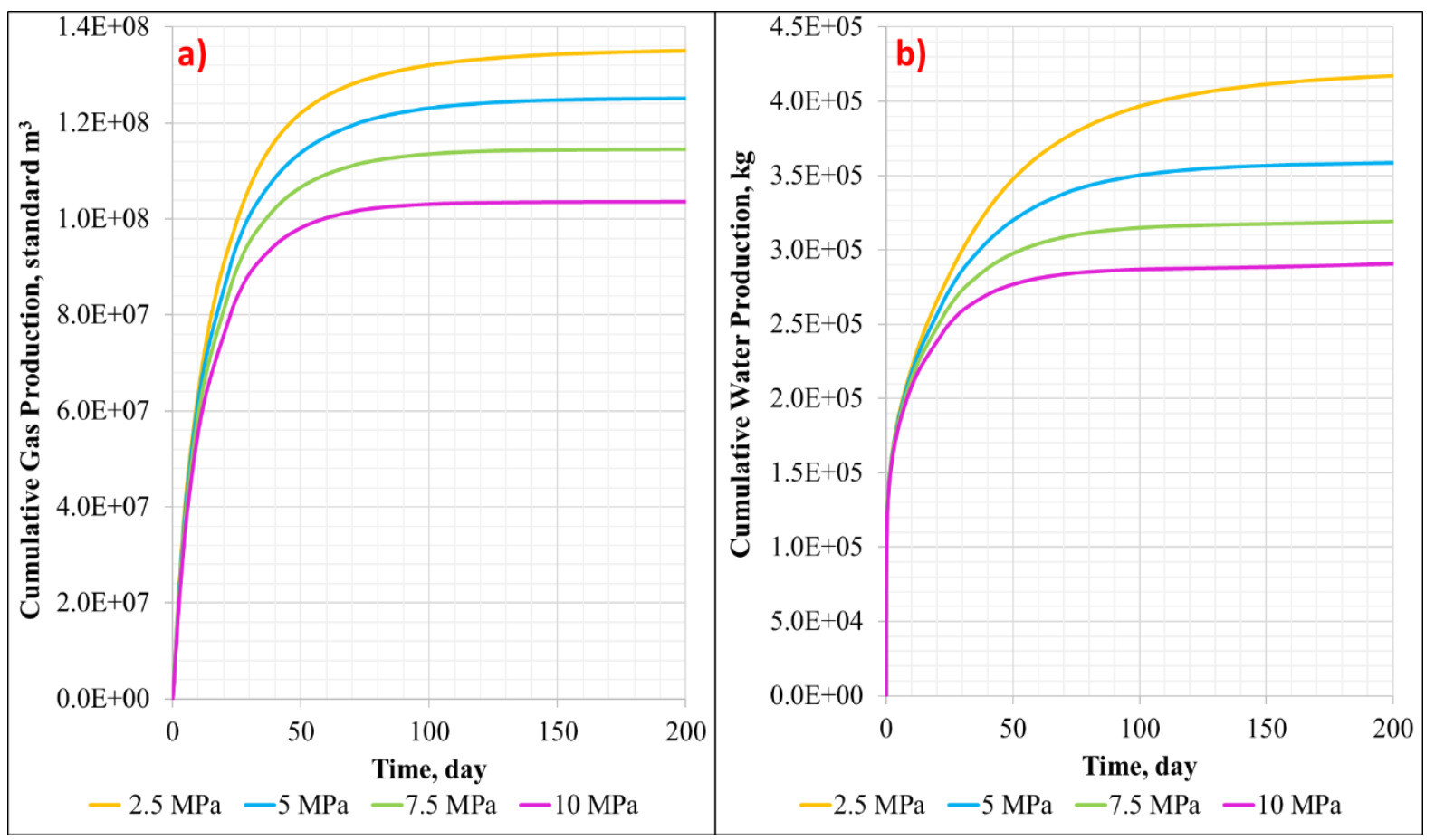

Figure 17. a) Cumulative gas production from gas zone b) Cumulative water production from gas zone for Case 4 when gas zone was prone to water flux for 10 days at different production pressures.

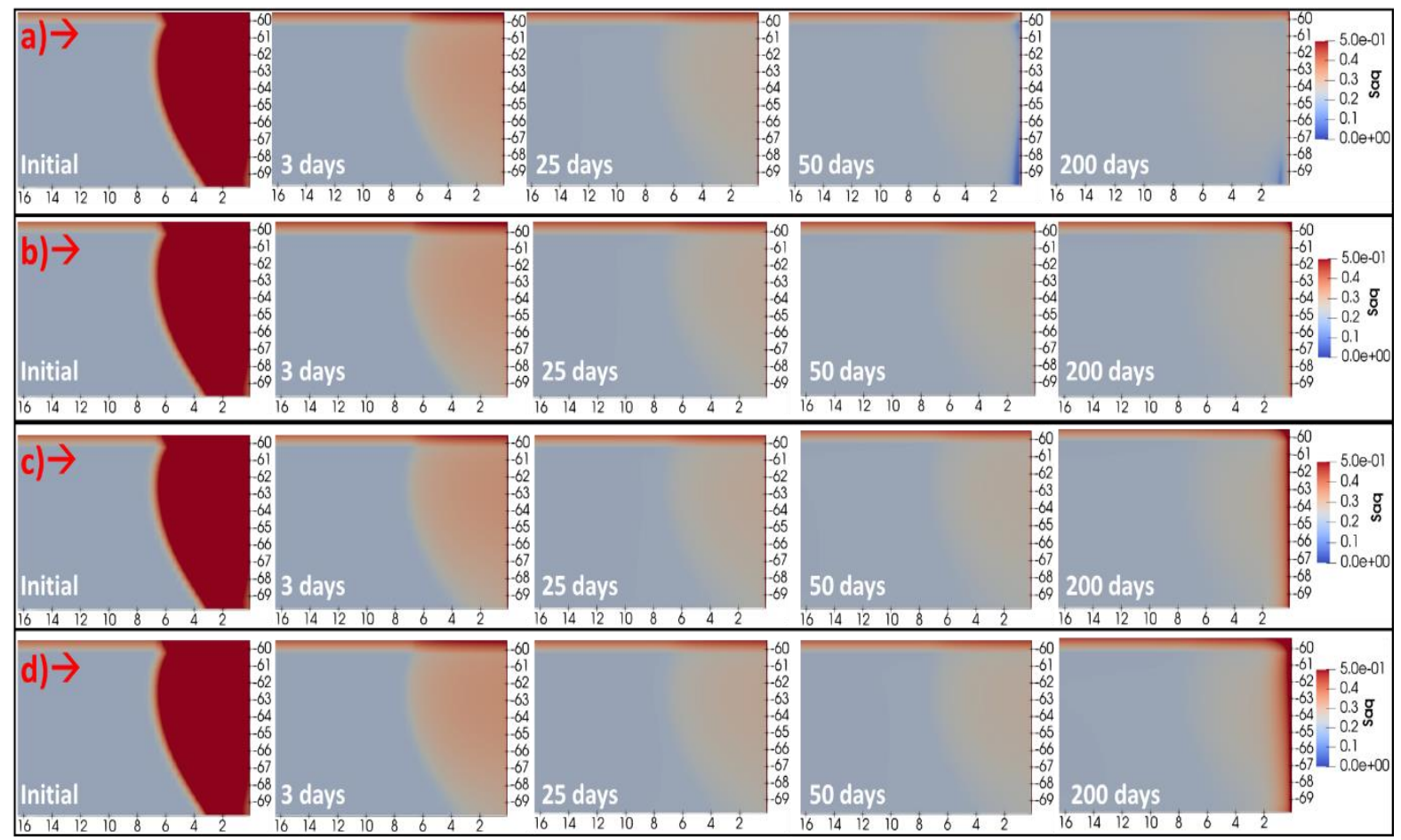

Figure 18. The change in water saturation distribution for Case 4 when gas zone was prone to water flux for 10 days at different production pressures: a) $2.5 \mathrm{MPa}$ b) $5 \mathrm{MPa}$ c) $7.5 \mathrm{MPa}$ d) $10 \mathrm{MPa}$. 
- After isolating water zone with well completion operations, gas production simulations from gas zone were held in this study. The water production from gas zone increased significantly because of the production of invaded water. Owing to water invasion from upper zone to gas zone, gas production was retarded.

- Fast production from gas zone did not disappear the remarks of water flux. Even in long durations, the water saturation distribution in gas zone did not return to its original case.

According to the results of this study, the analysis of well $\log$ data and the selection of completion techniques are quite important. If there are risks of perforating water saturated zone, TTP method should not be chosen. Before perforating the upper zone, gas zone should be isolated from the upper zone by setting packers or other completion techniques.

\section{Nomenclature}

\begin{tabular}{|c|c|c|c|}
\hline $\mathrm{CH}_{4}$ & methane & $\mathrm{C}_{2} \mathrm{H}_{6}$ & ethane \\
\hline $\mathrm{C}_{3} \mathrm{H}_{8}$ & propane & $n-C_{4} H_{10}$ & n-butane \\
\hline i- $\mathrm{C}_{4} \mathbf{H}_{10}$ & i-butane & $\mathrm{H}_{2} \mathrm{O}$ & water \\
\hline $\mathrm{CO}_{2}$ & carbon dioxide & $\mathrm{H}_{2} \mathrm{~S}$ & hydrogen sulfide \\
\hline $\mathrm{O}_{2}$ & oxygen & $\mathbf{N}_{2}$ & nitrogen \\
\hline $\mathrm{C}_{2} \mathrm{H}_{5} \mathrm{OH}$ & ethanol & $\mathrm{H}_{2}$ & hydrogen \\
\hline $\mathbf{M}_{\mathbf{k}}$ & $\begin{array}{l}\text { mass accumulation term of } \\
\text { component } \kappa\left(\mathrm{kg} / \mathrm{m}^{3}\right)\end{array}$ & $\mathbf{V}, \mathbf{V}_{\mathbf{n}}$ & $\begin{array}{l}\text { volume, volume of } \\
\text { subdomain } n\left(L^{3}\right)\end{array}$ \\
\hline $\mathbf{q}^{\mathrm{K}}$ & $\begin{array}{l}\text { source/sink term of component } \\
\left(\mathrm{kg} \mathrm{m}^{-3} \mathrm{~s}^{-1}\right)\end{array}$ & $F^{\kappa}$ & $\begin{array}{l}\text { Darcy flux vector of } \\
\text { component }\left(\mathrm{kg} \mathrm{m}^{-2} \mathrm{~s}^{-1}\right)\end{array}$ \\
\hline $\mathbf{t}$ & time, $\mathrm{s}$ & $A, \Gamma_{n}$ & $\begin{array}{l}\text { surface area, surface } \\
\text { area of subdomain } n\left(L^{2}\right)\end{array}$ \\
\hline$\varphi$ & porosity, fraction & $\mathbf{S}_{\beta}$ & $\begin{array}{l}\text { saturation of phase } \beta: A \text {, } \\
\text { Aqueous; } G \text {, gaseous; } H \text {, } \\
\text { solid halite }\end{array}$ \\
\hline$\rho_{\beta}$ & density of phase $\beta\left(\mathrm{kg} \mathrm{m}^{-3}\right)$ & $\mathbf{X}_{\beta}^{\kappa}$ & $\begin{array}{l}\text { mass fraction of } \\
\text { component } \kappa: g^{i}, \text { gas } \\
\text { component } ; \text {, water; } s \text {, } \\
\text { salt in phase } \beta(\mathrm{kg} / \mathrm{kg})\end{array}$ \\
\hline$\rho_{\mathrm{R}}$ & rock density $\left(\mathrm{kg} \mathrm{m}^{-3}\right)$ & $\psi^{i}$ & $\begin{array}{l}\text { the mass of adsorbed } \\
\text { component } g^{i} \text { per unit } \\
\text { mass of rock [kg/kg] }\end{array}$ \\
\hline$\delta_{\psi}^{i}$ & $\begin{array}{l}0 \text { when no adsorption } \\
1 \text { when adsorption exists }\end{array}$ & $\mathbf{P}_{\mathrm{dG}}$ & the dry gas pressure, $\mathrm{Pa}$ \\
\hline $\mathbf{m}_{\mathrm{L}}$ & $\begin{array}{l}\text { the total mass storage of } \\
\text { component } g^{i} \text { at infinite } \\
\text { pressure ( } k g \text { of gas } / k g \text { of matrix } \\
\text { material) }\end{array}$ & $\mathbf{P}_{\mathbf{L}}$ & $\begin{array}{l}\text { the pressure at which } \\
\text { half of this mass is stored } \\
(\mathrm{Pa})\end{array}$ \\
\hline $\mathbf{k}$ & rock intrinsic permeability $\left(\mathrm{m}^{2}\right)$ & $\mathbf{k}_{\mathrm{rG}}$ & $\begin{array}{l}\text { relative permeability of } \\
\text { the gaseous phase }\end{array}$ \\
\hline $\mathbf{k}_{\mathrm{rA}}$ & $\begin{array}{l}\text { relative permeability of the } \\
\text { aqueous phase }\end{array}$ & $\mathbf{g}$ & $\begin{array}{l}\text { gravitational } \\
\text { acceleration vector }(\mathrm{ms} \\
\text { 2) }\end{array}$ \\
\hline$\mu_{\mathrm{A}}$ & $\begin{array}{l}\text { viscosity of the aqueous phase } \\
\text { (Pa s) }\end{array}$ & $\mu_{\mathrm{G}}$ & $\begin{array}{l}\text { viscosity of the gaseous } \\
\text { phase (Pa.s) }\end{array}$ \\
\hline $\mathbf{P}_{\mathrm{A}}$ & $\begin{array}{l}\text { Pressure of the aqueous phase } \\
(\mathrm{Pa})\end{array}$ & $\mathbf{C}_{\mathrm{R}}$ & $\begin{array}{l}\text { heat capacity of the dry } \\
\operatorname{rock}\left(\mathrm{J} \mathrm{kg}^{-1} \mathrm{~K}^{-1}\right)\end{array}$ \\
\hline b & Klinkenberg $b$-factor & $\mathbf{U}_{\beta}$ & $\begin{array}{l}\text { specific internal energy } \\
\text { of phase } \beta(\mathrm{J} / \mathrm{kg})\end{array}$ \\
\hline $\mathbf{T}$ & Temperature, $K$ & $\mathbf{T}_{\text {ref }}$ & reference temperature, $K$ \\
\hline$N_{G}$ & Number of gas components & $\mathbf{K}_{\mathbf{n}}$ & $\begin{array}{l}\text { Knudsen dimensionless } \\
\text { number }\end{array}$ \\
\hline $\mathbf{r}_{\text {pore }}$ & Pore diameter, $m$ & $\lambda$ & $\begin{array}{l}\text { the mean free path of gas } \\
\text { molecules }\end{array}$ \\
\hline b & Klinkenberg b-factor & $\delta$ & $\begin{array}{l}\text { The collision diameter of } \\
\text { gas molecule, } m\end{array}$ \\
\hline $\mathbf{R}$ & Universal gas constant & $M$ & molecular weight \\
\hline$u^{i}$ & $\begin{array}{l}\text { specific internal energy of } \\
\text { adsorbed gas component gi [J } \\
\left.\mathrm{kg}^{-1}\right]\end{array}$ & $\mathbf{k}_{\mathrm{B}}$ & $\begin{array}{l}\text { Boltzmann constant, } \\
1.3805 \times 10^{-23} \mathrm{~J} /{ }^{\circ} \mathrm{K}\end{array}$ \\
\hline$J_{G}^{\kappa}$ & $\begin{array}{l}\text { the diffusive mass flux of } \\
\text { component } \kappa \text { in the gas phase } \\
{[\mathrm{kg} / \mathrm{m} 2 / \mathrm{s}]}\end{array}$ & $\overline{\boldsymbol{k}}_{\boldsymbol{\theta}}$ & $\begin{array}{l}\text { composite thermal } \\
\text { conductivity of the } \\
\text { medium/fluid ensemble } \\
{[W m-1 \mathrm{~K}-1]}\end{array}$ \\
\hline$\sigma_{0}$ & $\begin{array}{l}\text { Stefan-Boltmann Constant } \\
\left(5.6687 \times 10^{-8} \mathrm{~J} \mathrm{~m}^{-2} \mathrm{~K}^{-4}\right)\end{array}$ & fo & radiance emittance factor \\
\hline $\mathbf{H}_{\beta}$ & $\begin{array}{l}\text { specific enthalpy of phase } \beta: A \text {, } \\
G\left(\mathrm{~J} \mathrm{~kg}^{-1}\right)\end{array}$ & $S_{\text {irA }}$ & $\begin{array}{l}\text { irreducible saturation of } \\
\text { aqueous phase }\end{array}$ \\
\hline $\mathbf{S}_{\mathrm{irG}}$ & $\begin{array}{l}\text { irreducible saturation of } \\
\text { gaseous phase }\end{array}$ & $\mathbf{n}$ & $\begin{array}{l}\text { Modified Stone relative } \\
\text { permeability parameters }\end{array}$ \\
\hline$\lambda, \mathbf{P}_{0}$ & $\begin{array}{l}\text { van Genuchten capillary } \\
\text { pressure parameters }\end{array}$ & & \\
\hline
\end{tabular}

\section{Acknowledgement}

This study was completed with the supports of Scientific and Technological Research Council of Turkey (TUBITAK) under International Scientific Publications Encouragement Program.

\section{Author's Contributions}

Şükrü Merey: Drafted and wrote the manuscript, performed the numerical simulations and result analysis.

\section{Ethics}

There are no ethical issues after the publication of this manuscript.

\section{References}

1. Lea, JF, Nickens, HV. 2004. Solving gas-well liquid-loading problems, Journal of Petroleum Technology, 56(4), 30-36.

2. Turner, RG, Hubbard, MG, Dukler, AE. 1969. Analysis and Prediction of Minimum Flow Rate for the Continuous Removal of Liquids from Gas Wells, Journal of Petroleum Technology, 21(11), 1475-1482.

3. Okon, A., Appah, D., Akpabio, J. 2017. Water Coning Prediction Review and Control: Developing an Integrated Approach, Journal of Scientific Research and Reports, 14(4), 1-24.

4. Tătaru, A, Simescu, NB. Underbalance well completion - a modern approach for mature gas fields. 8th International Conference on Manufacturing Science and Education, Sibiu, Romania, 2017, pp $1-7$.

5. Joseph, A, Sand, CM, Ajienka, JA. Classification and Management of Liquid Loading in Gas Wells, The Nigeria Annual International Conference and Exhibition, Lagos, Nigeria, 2013, pp 1-25.

6. Anwar A, Hassan S, Belhadj B. An integrated approach to determine hydrocarbon potential in low resistivity, thinly laminated reservoir: East-Delta area, Egypt. In: MOC 2002, Alex, Egypt.

7. Islam, ARMT, Islam, MA, Tasnuva, A, Biswas, RK, Jahan, K. 2014. Petro physical parameter studies for characterization of gas reservoir of Narsingdi gas field, Bangladesh, International Journal of Advanced Geosciences, 2(2), 53-58.

8. Xi, F, Bing, Z, Xuefeng, Y, Hui, D. 2015. Effective water influx control in gas reservoir development: Problems and countermeasures, Natural Gas Industry B, 2, 240-246.

9. Jacobsen, S et al. 1991. Log Interpretation Strategies in Gas Wells, Oil Review, April, 22-34.

10. Wild Well Control (WWC), Completions and Workovers. https://www.wildwell.com/wp-content/uploads/Completions-andWorkover.pdf (accessed at 29.10.2018).

11. Cosad, C. 1992. Choosing a Perforation Strategy, Oilfield Review, October, 54-69.

12. McAleese, S. Operational Aspects of Oil and Gas Well Testing; Elsevier: Amsterdam, Netherland, 2000.

13. CNPC (China National Petroleum Corporation). Perforation Technology for Complex Reservoirs. Science \& Technology Management Department, 2011.

14. Ifediora, E, Ibrahim, C, Ekeke, D, Nwaochei, F, Ogugua, E., Orumwese, S, Idedevbo, K. A Novel Technology for Through Tubing Perforation in Highly Deviated Wells Where Electric Line 
Celal Bayar University Journal of Science

Volume 15, Issue 1, 2019, p 99-113

Doi: $10.18466 /$ cbayarfbe. 483578

Is Limited, 33rd SPE Nigerian Annual International Conference and Exhibition, Abuja, Nigeria, 2009, pp 1-6.

15. Marotta, M, Morsetti, C, Mazzoni, S, Diaf, R, Cherri, R Production Optimization in Plio-Pleistocene Sequences by Through Tubing Perforations and Sand Consolidation in Rigless Activities: Italian Case Histories, 13th Offshore Mediterranean Conference and Exhibition, Ravenna, Italy, 2017, pp 1-15.

16. Moridis, GJ, Freeman, CM. User's Manual for The RealGasBrine v1.0 Option of TOUGH+ v1.5: A Code for The Simulation of System Behavior in Gas-Bearing Geologic Media. Earth Sciences Division, Lawrence Berkeley National Laboratory, Berkeley, CA 94720 August 2014.

17. Ali, I, Malik, NA. A realistic transport model with pressure dependent parameters for gas flow in tight porous media with application to determining shale rock properties. https://arxiv.org/pdf/1610.05070.pdf (accessed at 17.11.2018)

18. Aguilera, R. 2016. Shale gas reservoirs: Theoretical, practical and research issues, Petroleum Research, 1,10-26.

19. Dai, S, Santamarina, JC. 2013. Water retention curve for hydratebearing sediments, Geophysical Research Letters, 40, 5637-5641.

20. Jang, J, Santamarina, JC. 2014. Evolution of gas saturation and relative permeability during gas production from hydrate-bearing sediments: Gas invasion vs. gas nucleation, Journal of Geophysical Research: Solid Earth, 119, 116-126. 